\title{
Urgensitas Masyarakat Madani Civil Society dalam Mengurai Problematika Sosial: Suatu Tinjauan Terhadap Varian Konflik di Lombok
}

\author{
Ihsan Hamid \\ UIN Mataram
}

Naskah diterima 20 Nov 2018, direvisi 3 Des 2018, disetujui 17 Jan 2019

Abstract Civil society movement post Reformation gained momentum, it is marked by a growing number of emerging elements of civil society itself with various forms of movement and activities performed. The dynamics of this at once indicates that the process of Westernization of the nation of Indonesia, because of the progress of the process therein, of course, involve the participation of the public good in giving control of the Government as well as the active participation in the effort of maintaining the harmony node civic social dam in an attempt to mecegah the conflict and remained consistent in providing solutions to the issues facing the nation. On that basis then the existence of a civil society necessary existence. For it was at least the civil society movement can be manifested into some kind of social movements. The first symbolic resistance, which includes various indirect actions to control the domination of the country. Secondly, pragmatic resistance that was conducted as a direct reaction against the wisdom of the Government or the system of socio-economic-political progress, including in this case be a solution for all social problems. Third, the symbolic resistance-which is a pragmatic action directly or indirectly to the creation of socio-political situation that demands better especially young wong and also demanded a reduction in State control against the various areas of life the community.

Keywords: Civil Society; Democracy; The moral; Politics..

Abstrak Gerakan civil society pasca reformasi mendapatkan momentum yang tepat, hal ini ditandai dengan semakin banyaknya muncul elemenelemen civil society itu sendiri dengan berbagai bentuk gerakan dan kegiatan yang dilakukan. Dinamika ini sekaligus menunjukkan bahwa proses berdemokrasi bangsa Indonesia mengalami kemajuan, karena proses didalamnya sudah barang tentu melibatkan partisipasi publik baik dalam memberikan control terhadap pemerintah maupun peran serta aktif dalam upaya menjaga keharmonisan simpul sosial kemasyarakatan dalam upaya mecegah konflik serta tetap konsisten dalam memberikan solusi atas persoalan bangsa yang dihadapi. Atas dasar itu maka keberadaan civil society sangat dibutuhkan 
keberadaannya. Untuk memerankan hal itu setidaknya gerakan civil society tersebut dapat dimanifestasikan ke dalam beberapa jenis gerakan sosial. Pertama, resistensi simbolik yang meliputi pelbagai aksi tidak langsung untuk mengontrol dominasi negara. Kedua, resistensi pragmatis yang dilakukan sebagai reaksi langsung terhadap kebijaksanaan pemerintah atau sistem sosial-ekonomi-politik yang sedang berjalan, termasuk dalam hal ini menjadi solusi atas segala permasalahan sosial. Ketiga, resistensi simbolik-pragmatis yang merupakan aksi langsung maupun tidak langsung yang menuntut terciptanya situasi sosial-politik yang lebih baik terutama wong cilik dan juga menuntut pengurangan kontrol negara terhadap pelbagai bidang kehidupan masyarakat.

Kata Kunci: Civil Society; Demokrasi; Moral; Politik..

\section{A. PENDAHULUAN}

Indonesia, sejak tumbangnya orde baru dan lahirnya orde reformasi hingga sekarang, terus diwarnai oleh adegan-adegan konflik yang terjadi di mana-mana. Mulai dari konflik yang diakibatkan oleh faktor politik, ekonomi, sosial, budaya dan bahkan agama. Konflik di Aceh, Poso, Ambon, Mesuji, Bima, Lombok dan Daerah-daerah lainnya, cukup telah menjadi bukti bahwa konflik di Indonesia sudah sedemikian parah dan hampir merata terjadi di sebagian besar wilayah Indonesia. Peristiwaperistiwa itu tentu sangat bertolak belakang dengan apa yang dicitacitakan oleh bangsa Indonesia yaitu suasana damai, adil dan makmur bagi seluruh lapisan masyarakatnya.

Menyadari hal tersebut di atas, maka perlu dicari upaya untuk segera memperbaiki keadaan masyarakat yang kian hari makin amburadul (tidak karuan dan tidak terkendali). Jalan keluar yang paling tepat adalah kembali kepada ajaran agama masing-masing dan mengoptimalkan peran masyarakat madani (civil society), yang pada akhirnya jalan tersebut akan menumbuhkan kesadaran kita akan pentingnya rasa aman dan hidup harmonis. Namun hal tersebut tidak mudah dilakukan begitu saja tanpa mengoptimalkan kualitas sumber daya manusia. Hal ini dapat terlaksana apabila semua bidang pembangunan bergerak secara terpadu yang menjadikan manusia sebagai pelaku di dalamnya. Pengembangan masyarakat sebagai sebuah kajian keilmuan dapat menyentuh keberadaan manusia yang berperadaban. Pengembangan masyarakat merupakan sebuah proses 
yang dapat merubah watak, sikap, dan prilaku masyarakat ke arah pembangunan yang dicita-citakan.

Indikator dalam menentukan kemakmuran suatu bangsa sangat tergantung pada situasi dan kondisi serta kebutuhan masyarakatnya. Akhir-akhir ini masyarakat Indonesia mencuatkan suatu kemakmuran yang didambakan yaitu terwujudnya masyarakat madani. Munculnya istilah masyarakat madani pada era reformasi ini, tidak terlepas dari kondisi politik negara yang berlangsung selama ini. Sejak Indonesia merdeka, masyarakat belum merasakan makna kemerdekaan yang sesungguhnya. Pemerintah atau penguasa belum banyak memberi kesempatan bagi semua lapisan masyarakat mengembangkan potensinya secara maksimal. Bangsa Indonesia belum terlambat mewujudkan masyarakat madani, asalkan semua potensi sumber daya manusia mendapat kesempatan berkembang dan dikembangkan. Mewujudkan masyarakat madani banyak tantangan yang harus dilalui. Untuk itu perlu adanya strategi peningkatan peran dan fungsi masyarakat dalam mengangkat martabat manusia menuju masyarakat madani itu sendiri.

Berangkat dari itu, maka artikel ini bermaksud mencoba membahas sedikit tentang diskursus antra civil society dan masyarakat madani, yang kemudian baru disusul dengan bahasan tentang peran masyarakat madani (civil society) di Lombok dalam mengurai konflik. Hal ini dilakukan sebagai sebuah upaya untuk mencoba memetakan pentingnya peran civil society dalam membendung terjadinya konflik dan masalah sosial lainnya. Untuk berupaya melakukan itu tentu saja saya akan memanfaatkan beberapa pondasi pemikiran yang telah dibangun sejumlah pemikir yang akan dibahas, dalam bahasan selanjutnya di bawah. Sehingga tercipta sebuah upaya sinergis dengan harapan dapat melahirkan sebuah gagasan lokalitas. Dengan demikian, pembahasan dalam artikel ini diharapkan dapat memberikan sedikit kontribusi dalam upaya untuk memperkaya wacana dan gagasan kita, baik dalam tataran ilmiah maupun praktis.

\section{B. PEMBAHASAN}

Diskursus Konsep Civil Society dan Konsep Masyarakat Madani; Sejarah Kemunculan dan Pengertiannya

Mencari padanan kata "civil society" dalam literatur bahasa kita memang agak sulit. Kesulitan ini tidak hanya disebabkan adanya hambatan 
psikologis untuk menggunakan istilah-istilah tertentu yang berbau Barat non-Islam, tetapi juga karena tiadanya pengalaman empiris diterapkannya nilai-nilai "societys" dalam tradisi kehidupan sosial dan politik bangsa. Namun banyak orang menyepadankan istilah ini dengan masyarakat madani dalam istilah Indonesia, societas civilis (Romawi) atau koinonia politike (Yunani). Padahal istilah civil society dan masyarakat madani berasal dari dua sistem budaya berbeda. Masyarakat madani merujuk tradisi Arab-Islam, sedang civil society pada tradisi Barat non-Islam (Jainuri, 2000:22; Fikri, 2018). Perbedaan ini bisa memberikan makna berbeda apabila dikaitkan dengan konteks asal istilah itu muncul.

Oleh karena itu, pemaknaan lain di luar derivasi konteks asalnya akan merusak makna aslinya. Ketidaksesuaian pemaknaan ini tidak hanya menimpa kelompok masyarakat yang menjadi sasaran aplikasi konsep tersebut, tetapi juga para interpreter yang akan mengaplikasikannya dalam tataran ilmiah. Hal lain yang berkaitan dengan perbedaan aplikasi kedua konsep masyarakat ini adalah bahwa civil society telah teruji secara terus-menerus dalam tatanan kehidupan sosial-politik Barat hingga mencapai maknanya yang terakhir, yang turut membidani lahirnya peradaban Barat modern.

Sedangkan masyarakat madani seakan merupakan keterputusan konsep ummah yang merujuk pada masyarakat Madinah yang dibangun oleh Nabi Muhammad dan lebih bercorak Islami. Idealisasi tatanan masyarakat Madinah ini didasarkan atas keberhasilan Nabi mempraktekkan nilai-nilai keadilan, ekualitas, kebebasan, penegakan hukum, dan jaminan kesejahteraan bagi semua warga serta perlindungan terhadap kaum lemah dan kelompok minoritas. Meskipun secara ideal eksistensi masyarakat Madinah ini hanya sebentar tetapi secara historis memberikan makna yang sangat penting sebagai rujukan masyarakat di kemudian hari untuk membangun kembali tatanan kehidupan yang sama. Dari pengalaman sejarah Islam masa lalu ini, masyarakat Madinah yang dibangun oleh Nabi Muhammad secara kualitatif dipandang oleh sebagian kalangan intelektual muslim sejajar dengan konsep civil society (Anwar Ibrahim, 1996: 104). Sebagai upaya untuk memperjelas konsep dari masing-masing istilah tersebut, maka penulis akan mencoba mengurai dalam bahasan berikut. 


\section{Konsep Civil Society}

Istilah civil society berasal dari bahasa Latin yaitu civilis societas yang mula-mulanya sudah dipakai oleh Aristoteles (384-322 SM), ia memandang civil society sebagai sistem kenegaraan atau identik dengan negara itu sendiri. Selanjutnya istilah ini kemudian dipakai oleh Marcus Tullius Cicero (106-43 SM), seorang orator, politisi dan filosof Roma. Mengistilahkan masyarakat sipil dengan sociates civiles, yaitu sebuah komunitas yang lain. Istilah Cicero ini lebih menekankan pada konsep negara kota (city-state), dengan kata lain Cicero ingin mengatakan bahwa konsep negara kota merupakan pusat kebudayaan dan pemerintahan yang di dalamnya terdapat kumpulan masyarakat (Tim ICCE UIN Syarif Hidayatullah Jakarta, 2008: 195 dan Dawam Raharjo, 2008, 137). Sejak saat itu sampai dengan abad ke-18, pengertian civil society masih disamakan dengan negara (the state), yakni sekelompok masyarakat yang mendominasi seluruh kelompok lain.

Dalam rentang waktu yang cukup panjang istilah itu tidak banyak dikembangkan lagi, namun pada sekitar abad 15-17-an Thomas Hobbes (1588-1679), John Locke (1632-1704) dan Jean-Jacques Rousseau (1712-1778) kembali menghidupkan dan mengembangkan istilah civil society (masyarakat sipil) dengan merujuk kepada masyarakat dan politik. Menurut Hobbes, misalnya, berpendapat bahwa civil society mempunyai peran untuk meredam konflik dalam masyarakat sehingga ia harus memiliki kekuasaan mutlak, sehingga ia mampu mengontrol dan mengawasi secara ketat pola-pola interaksi setiap warga negara (Tim ICCE UIN Syarif Hidayatullah Jakarta, 2008: 195). Adapun menurut Locke, ia mendefinisikan masyarakat sipil sebagai masyarakat politik (political society) yang mana dihadapkan dengan keadaan alami (state of nature) sekelompok manusia. Masyarakat politik atau warga negara itu sendiri, menurut Rousseau yang senada dengan Hobbes, merupakan hasil dari suatu proses sosial. Namun perlu digarisbawahi bahwa pengertian-pengertian ini lahir ketika perbedaan antara masyarakat sipil dan negara belum dikenal, sehingga negara merupakan bagian dari masyarakat sipil yang mengontrol pola-pola interaksi warga negaranya atau dengan kata lain bahwa civil society masih bagian dari negara itu sendiri.

Kemudian barulah pada paruh kedua abad 18 Adam Ferguson (1723-1816) dan Thomas Paine (1737-1809) memberi tekanan lain terhadap makna civil society. Dimana civil society dan negara dipahami 
sebagai dua buah entitas yang berbeda, sejalan dengan proses pembentukan sosial dan perubahan-perubahan struktur politik sebagai akibat pencerahan (enlightment). Keduanya diposisikan dalam posisi yang diametral. Masyarakat sipil bahkan dinilai sebagai anti tesis terhadap negara, ia harus lebih kuat untuk mengontrol negara demi kepentingannya (yusron, 2009: 16. Nampakanya dalam fase perkembangan ini makna civil society sudah berkembang sangat luas. Ini terbukti dengan mulai berkembangnya paradigma baru dalam melihat civil society yang berbeda dari negar itu sendiri.

Namun, pemahaman dan paradigma ini kemudian mengundang reaksi dari para pemikir lainnya seperti Hegel (1770-1831) yang beraliran idealis. Menurutnya civil society tidak dapat dibiarkan tanpa terkontrol. Ia justru memerlukan berbagai macam aturan dan pembatasan melalui kontrol hukum, administrasi dan politik. Lebih lanjut, Hegel membedakan masyarakat politik (the state) dan masyarakat sipil (civil society). Masyarakat politik adalah perkumpulanperkumpulan yang mengandung aspek politik yang mengayomi masyarakat secara keseluruhan. Sedangkan masyarakat sipil ialah perkumpulan merdeka yang membentuk apa yang disebut sebagai masyarakat borjuis (Chandran Kukathas, 2004: 55). Konsep ini memiliki tingkat relevansi yang tinggi jika melihat realitas pada waktu itu, kontrol civil society yang berupa hukum, tertib administrasi menjadi penting sebagai bagiana dalam menciptakan keseimbangan dan stabilitas sosial.

Baru kemudian Karl Marx (1818-1883) sependapat dengan Hegel dalam melihat civil society sebagai masyarakat borjuis. Bedanya, Hegel menganggap hanya melalui negaralah, kepentingan-kepentingan masyarakat yang universal dan mengandung potensi konflik bisa terselesaikan. Sedangkan Marx berpandangan sebaliknya, ia menganggap negara tak lain sebagai badan pelaksana kepentingan kaum borjuis. Oleh sebab itu, negara harus dihapuskan, atau harus diruntuhkan oleh kelas proletar. Ketika negara akhirnya lenyap, maka yang tinggal hanyalah masyarakat tanpa kelas (Chandran Kukathas, 2004: 54). Visi ini berseberangan dengan visi Hegel yang mengatakan di masa depan masyarakat sipillah yang akan runtuh dari dalam, jika negara telah mampu mengayomi seluruh kepentingan masyarakat. Sedangkan menurut Antonio Gramsci (1891-1937) yang juga memandang civil society sebagai milik kaum borjuis yang akhirnya menjadi pendukung negara, disamping mereka memegang hegemoni, 
mereka juga seharusnya bisa menjalankan fungsi etis dalam mendidik dan mengarahkan perkembangan ekonomi masyarakat (Dawam Raharjo, 2000:18-22). Dalam arti, disini Gramsci memandang bahwa civil society bukan sekedar basis material dalam hubungannya dengan produksi dan kapital sebagaimana yang diutarakan oleh Marx akan tetapi menurutnya ia lebih menempatkan civil society dalam wilayah yang lebih luas yakni wilayah superstruktur (Asrori S. Karni, 1999: 4) wilayah atau tempat terjadinya proses perebutan posisi hegemonik dengan meliputi motif dan varian yang lebih luas-proses ini memungkinkan munculnya kontra hegemoni dari luar kekuatan negara. Cerita akhir dari semua proses ini adalah terserapnya negara dalam civil society, sehingga kemudian terbentuklah sebuah masyarakat yang teratur (regulated societed).

Dan adapun kemudian menurut Alexis de Tocqueville (1805-1859), masyarakat sipil tidak secara a priori subordinatif terhadap negara, tetapi lebih dari itu ia bersifat otonom dan memiliki kapasitas politik cukup tinggi sehingga mampu menjdi kekuatan penyeimbang menghadapi intervensi negara dan tidak hanya berorientasi pada kepentingan sendiri tetapi juga terhadap kepentingan publik. Pendapat ini kemudian diperkuat oleh Hannah Arendt (1906-1975) dan Jurgen Habermas (1929-) dengan konsep a free public sphere, sebuah wilayah di mana masyarakat sebagai warga negara memiliki akses penuh terhadap setiap kegiatan public (Mawardi, 2008: 21). Penciptaan ruang publik, bagi Arendt merupakan prasyarat terciptanya civil society dan demokratisasi. Hal senada diungkapkan Ernest Gellner (1925-1995) yang memandang perlunya ruang dan kebebasan publik. Menurutnya civil society adalah seperangkat institusi non pemerintah yang cukup kuat untuk mengimbangi negara dan mencegah timbulnya tirani kekuasaan (Sufyanto, 2001: 82-90). Hingga kemudian sampai saat ini civil society sudah sedemikian berkembang dalam paradigma pemahamannya dan hampir semua sependapat bahwa civil society tetap berbeda dengan konsep negara-kota, dalam arti civil society merupakan entitas yang berdiri sendiri serta mandiri bebas tidak terikat dengan negara.

Hal itu senada dengan apa yang diungkapkan oleh Komaruddin Hidayat dan Ahmad Gaus AF dalam pengantarnya di buku Islam Negara dan Civil Society yang menuliskan bahwa dalam faham civil society, rakyat bukanlah subordinat negara melainkan partner yang setara dan 
memiliki fungsi kontrol terhadap pemerintah dan sebaliknya (Komaruddin Hidayat dan Ahmad Gaus AF, 2005: xix). Sehinga dalam hal ini negara tidak bisa semena-mena terhadap rakyat akan tetapi dalam hal ini negara memiliki peran sebagai pengayom, pelaksana mandat rakyat dan lain sebagainya.

Dan secara umum civil society sebagaimana yang dikonsepsikan oleh para pemikirnya mempunyai tiga ciri khusus yaitu: pertama, adanya kemandirian yang cukup tinggi dari individu-individu dan kelompok dalam masyarakat, terutama saat berhadapan dengan negara. Kedua, adanya ruang publik bebas sebagai wahana bagi keterlibatan politik secara aktif dari warga negara demi kepentingan publik. Ketiga, adanya kemampuan membatasi kuasa negara agar tidak intervensionis dan otoriter.

Sehingga secara kongkrit, civil society bisa berwujud dalam bentuk berbagai organisasi yang berada di luar institusi-institusi pemerintah yang mempunyai cukup kekuatan untuk melakukan counter atau mengimbangi terhadap negara, misalnya seperti organisasi seperti NU, Muhammadiyah, Persis, NW dan lain-lainya. Atau, berupa kelompokkelompok yang melakukan gerakan sosial politik untuk menuntut adanya transformasi demokrasi meski mungkin tidak terorganisir ketat seperti kelompok keluarga atau RT, buruh, petani dan sebagainya.

\section{Konsep Masyarakat Madani}

Istilah dan Konsep masyarakat madani pertama kali diperkenalkan di Indonesia oleh Anwar Ibrahim yang saat itu menjabat sebagai Menteri Keuangan dan Asisten Perdana Menteri Malaysia, ketika menyampaikan pidatonya pada Simposium Nasional pada Festival Istiqlal 1995 (Dawam Raharjo, 2000:145). Dan istilah inipun terbilang baru, walaupun Prof. Naquib al-Attas, yang merupakan seorang ahli sejarah dan peradaban Islam dari Malaysia sekaligus pendiri ISTAC-lah yang mula-mula mencetuskannya. Kata "madani" pada masyarakat madani seringkali dipadankan dengan kata hadlari, tsaqafi atau tamaddun dalam bahasa Arab yang mana mengacu pada hal-hal yang ideal dalam kehidupan (Sufyanto, 2001: 93-94) yang meliputi agama, peradaban dan perkotaan.

Dalam persefektif Islam, masyarakat madani lebih mengacu kepada penciptaan peradaban. Kata al Din, yang umumnya diterjemahkan sebagai agama, berkaitan dengan makna al tamaddun atau peradaban. Keduanya menyatu ke dalam pengertian al madinah (mufrod) atau al 
mada'in (jamak) yang artinya kota. Hanya saja dalam Al-Quran, pengertian kota tidak hanya diwakili oleh satu kata. Kata al qoryah dan al balad, juga berarti kota, walupun keduanya sering pula diterjemahkan sebagai negeri. Tetapi dalam perkataan negeri itupun terkandung pengertian peradaban dan kebudayaan. Karena dalam perkataan negeri terdapat pengertian tentang suatu daerah yang dihuni manusia. Disitu ada manusia, disitu pula ada peradaban dan kebudayaan (Raharjo, 2000:147).

Nurholis Madjid yang menjadi motor utama konsep ini di Indonesia misalnya mengartikan masyarakat madani sebagai masyarakat yang berperadaban (ber-madaniyyah) karena tunduk dan patuh (danayadinu) kepada ajaran kepatuhan (din) yang dinyatakan dalam supremasi hukum dan peraturan. Ia pada hakikatnya adalah reformasi total terhadap masyarakat tak kenal hukum (lawless) Arab jahiliyah, dan terhadap supremasi kekuasaan pribadi seorang penguasa seperti yang selama ini menjadi pengertian umum tentang negara (Nurholis Majid, 1999, 153). Lebih lanjut ia juga mengatakan bahwa Nabi Muhammad secara konkrit telah meletakkan dasar-dasar masyarakat madani ketika beliau telah menetap di Madinah. Keberhasilan itu tampak jelas ketika beliau berhasil menyatukan dua pengikut setianya yakni kaum Ansor dan kaum Muhajjirin yang kemudian menggariskan ketentuan bermasyarakatnya dalam dokumen yang dikenal dengan Piagam Madinah. Dalam dokumen itulah umat manusia untuk pertama kalinya diperkenalkan, antara lain, kepada wawasan kebebasan, terutama di bidang agama dan ekonomi, serta tanggung jawab sosial dan politik khususnya pertahanan secara bersama.

Yang menarik pula dari perpindahan Nabi Muhammad SAW ke Madinah ialah terjadinya perubahan nama kota Yatsrib yang oleh beliau diganti menjadi Madinah. Penggantian nama Madinah bukan sekedar nama tetapi mengandung konsep masyarakat. Jika Al-Quran menyebut istilah khiru ummah dan ummatan washoatan, maka nama Madinah mengandung arti negeri dimana penduduknya hidup secara beradab atau berperadaban tinggi. Jika dilengkapi dengan Munawwarah maka artinya menjadi peradaban tinggi yang disinari dan diterangi oleh wahyu ilahi (Al-Munawar, dkk, 2003: 93-94). Karena itu ada proses logis yang ditempuh oleh nabi dalam menegakkan pilar-pilar masyarkat madani di madinah, antra lain: mempersaudarakan pengungsi Makkah, menata pergaulan sosial, menjalin perjanjian perdamaian dan menegakkan 
hukum yang disepakati bersama. Dan di Madinah itu pula sebagai pembelaan kepada masyarakat madani, nabi dan kaum beriman diizinkan mengangkat senjata untuk perang membela diri dalam menghadapi musuh-musuh peradaban.

Selain itu, M. Dawam Raharjo yang menjadi salah seorang motor utama konsep ini juga misalnya dengan detil menjelaskan dan mengartikan masyarakat madani sebagai sebuah tatanan masyarakat yang berperadaban dan mengacu kepada nilai-nilai kebajikan umum, yang disebut al hair (Raharjo, 2000:153), Yang didalamnya mengandung nilai-nilai persatuan, keadilan, perdamaian, kesamaan dan kebebasan dalam arti bebas memilih jalan hidup masing-masing. Selanjutnya, ia menjelaskan, dasar utama dari masyarakat madani adalah persatuan dan integrasi sosial yang didasarkan pada suatu pedoman hidup, menghindarkan diri dari konflik dan permusuhan yang menyebabkan perpecahan dan hidup dalam satu persaudaraan.

Dalam tulisan yang berbeda Din Syamsudin juga mengatakan bahwa Masyarakat madani secara umum bisa diartikan sebagai suatu masyarakat atau institusi sosial yang memiliki ciri-ciri antara lain : kemandirian, toleransi, kesewadayaan, kerelaan menolong satu sama lain, dan menjunjung tinggi norma dan etika yang disepakati secara bersama-sama (Syamsuddin, 1999:12), tampaknya din disini lebih melihat konsep masyarakat madani sebagai sebuah tatanan sosial yang didalamnya terdapat syarat yang menjadi penentu utama terbentuknya masyarakat madani itu sendiri.

Sejalan dengan ide-ide di atas, menurut Azyumardi Azra, masyarakat madani lebih dari sekedar gerakan pro-demokrasi, karena ia juga mengacu pada pembentukan masyarakat berkualitas dan bertamaddun (civility). Sivilitas keniscayaan toleransi, yakni kesediaan individuindividu untuk menerima berbagai pandangan politik dan sikap sosial yang berbeda. Itu berarti, tidak ada satu pihak manapun, termasuk pemerintah dan gerakan-gerakan prodemokrasi, yang berhak memaksakan aspirasi dan kemauannya sendiri apakah dengan bentuk kooptasi, regimentasi, apalagi dengan hura-hura yang pada gilirannya hanya menimbulkan lawlessness dan sosial cost yang sering amat mahal (Azra, 1999: 7). Tampaknya Azra melihat konsep masyarakat madani lebih luas lagi, karena ia melihat bahwa masyarakat madani harus benar-benar memiliki public spare untuk menunjang teciptanya madani itu sendiri. 
Dari berbagai pendapat para cendikiawan di atas, jelas konsepkonsep itu merupakan suatu usaha untuk menganalisa model kajian kontekstual terhadap performa yang diinginkan dalam mewujudkan masyarakat madani. Hal tersebut dapat dilihat dari perbedaan penekanan dalam mensyaratkan idealisme terciptanya masyarakat madani. Akan tetapi secara global dari beberapa batasan di atas dapat ditarik benang emas, bahwa yang dimaksud dengan masyarakat madani adalah sebuah kelompok atau tatanan masyarakat yang berdiri secara mandiri dihadapan penguasa dan negara, memiliki ruang publik dalam mengemukakan pendapat, adanya lembaga-lembaga yang mandiri yang dapat menyalurkan aspirasi dan kepentingan publik.

Lebih luas lagi, dalam masyarakat madani, warga negara harus bekerjasama membangun ikatan sosial, jaringan produktif dan solidaritas kemanusiaan yang bersifat non-govermental untuk mencapai kebaikan bersama. Karena itu, tekanan utama masyarakat madani adalah terletak pada independensinya terhadap negara. Masyarakat madani berkeinginan membangun hubungan yang konsultatif bukan konfrontatif antara warga negara dan negara. Masyarakat madani juga tidak hanya bersikap dan berperilaku sebagai citizen yang memiliki hak dan kewajiban, melainkan juga harus menghormati equal right, memperlakukan semua warga negara sebagai pemegang hak kebebasan yang sama.

Disinilah kemudian, masyarakat madani menjadi alternatif pemecahan problematika sosial, dengan pemberdayaan dan penguatan daya kontrol masyarakat terhadap kebijakan-kebijakan pemerintah yang pada akhirnya nanti terwujud kekuatan masyarakat sipil yang mampu merealisasikan dan mampu menegakkan konsep hidup yang demokratis dan menghargai hak-hak asasi manusia. Dan kita percaya masyarakat madani dapat dijadikan sebagai alternatif paling tepat bagi demokratisasi, atau salah satu model solusi dalam mengurai konflik terutama di negara yang demokrasinya mengalami ganjalan akibat kuatnya hegemoni negara seperti Indonesia pada masa orde baru.

\section{Apakah Konsep Civil Socety dan Konsep Masyarakat Madani sama?}

Menyimak dua uraian singkat tentang konsep civil society dan konsep masyarakat madani di atas, kemudian muncul pertanyaan apakah civil society sama dengan masyarakat madani. Untuk menjawab dan merumuskan pertanyaan tersebut lagi-lagi disini saya akan 
mengemukakan beberapa pendapat para cendikiawan yang intens dalam mengamati dan menulis tentang dua konsep tersebut.

Konsep civil society dan konsep masyarakat madani yang sedang banyak dikembangkan sekarang ini memang memiliki sejarah tersendiri, dimana keduanya dilahirkan dalam tradisi yang berbeda. Namun, di sini penulis akan mencoba sedikit mendudukkan dua konsep tersebut sebagai suatu bentuk dialog Islam dengan modernisasi yang selama ini banyak dilakukan oleh para cendikiawan muslim. Masyarakat madani kadang dipahami sebagai masyarakat sipil, karena diterjemahkan dari konsep civil society yang lahir di Barat pada abad ke-18 dengan tokohnya John Locke atau Montesquieu. Namun, sebelumnya pada zaman Yunani Kuno sudah dikenal societies civilis, namun dengan pengertian yang identik dengan negara (Karnil, 1999:45).

Civil society yang dimaksudkan guna mencegah lahirnya pemerintahan otoriter melalui kontrol dari masyarakat. Berdasarkan sejarah awal Islam sebagai patokan-pada masa Nabi Muhammad SAW-, umat Islam menerjemahkan civil society dengan masyarakat madani, yaitu suatu masyarakat yang diciptakan Nabi Muhammad SAW di Madinah. Karena ciri-ciri kehidupan yang ideal pada masa Nabi Muhammad SAW dianggap sebagai proto-type masyarakat modern. Hal tersebut merupakan bentuk dialog Islam dengan modernitas sesuai dengan hukum dialektika. Dialog tersebut bersifat aktif karena Barat mengembangkan konsep civil society tersebut berdasarkan sejarah awal Islam.

Sejalan dengan itu, maka M. Dawam Raharjo berpendapat dengan menyatakan bahwa terjemahan untuk konsep civil society dan masyarkat madani adalah kebetulan dan tepat (Raharjo, 2000:146). Dalam arti bahwa substansi dari dua konsep itu memang memiliki kesamaan sehingga ia lebih cendrung menyamakan dua istilah tersebut. Hal senada juga diungkapkan masing-masing oleh Ayzumardi Azra, Nurholis Majid dan Din Samsudin.

Bertolak dari pendapat para tokoh cendikiawan tersebut lalu banyak kemudian para ilmuan muslim khususnya di Indonesia berpendapat bahwa istilah civil society yang lahir di Barat kemudian diislamkan menjadi masyarakat madani, yaitu suatu masyarakat kota Madinah bentukan Nabi Muhammad SAW. Mereka mengambil contoh dari data historis Islam yang secara kualitatif dapat dibandingkan dengan masyarakat ideal dalam konsep civil society. Mereka melakukan 
penyetaraan itu untuk menunjukkan bahwa di satu sisi dan hal-hal tertu, Islam mempunyai kemampuan untuk diinterpretasi ulang sesuai dengan perkembangan zaman, dan di sisi lain, masyarakat kota Madinah merupakan proto-type masyarakat ideal produk Islam yang bisa dipersandingkan dengan konsep civil society.

Sehingga hemat saya, rasanya tidaklah berlebihan kalau kita menerjemahkan civil society dengan masyarakat madani, karena kehidupan masyarakat Madinah di bawah Nabi Muhammad SAW dan Khulafaur Rasyidin sangat menjunjung tinggi prinsip-prinsip yang ada dalam civil society yang lahir di Barat. Dengan demikian, konsep masyarakat madani merupakan bentuk dialog Islam dengan modernitas (Barat). Reinterpretasi Islam terhadap perkembangan zaman bukan sesuatu yang tabu melainkan suatu keharusan dari hukum dialektika thesis-antithesissynthesis dalam rangka menuju ke arah yang lebih baik. Dialog dialektik Islam dan Barat bersifat aktif, karena sebelumnya Barat telah melakukan studi perbandingan dengan peradaban Islam ketika mau merumuskan civil society. Pada waktu itu, Barat sedang dalam cengkeraman pemerintahan otoriter, dan menilai sistempemerintahan Nabi Muhammad SAW adalah sangat baik.

Oleh sebab itu, dalam posisi ini saya cendrung setuju dengan penyamaan dua istilah tersebut. Sehingga penggunaan dua kata tersebut dalam tulisan saya ini memiliki makna yang sama tanpa harus dibedabedakan. Dengan asumsi bahwa konsep civil society dan konsep masyarkat madani sama-sama mengidealkan sebuah kondisi masyarakat yang di didalamnya terdapat nilai-nilai luhur keadilan, persamaan, kebebasan, dan toleransi.

\section{Karakteristik Masyarakat Madani (Civil Society)}

Masyarakat madani tidak lahir dengan sendirinya begitu saja. Melainkan ia lahir dari sebuah proses dan membutuhkan unsur-unsur sosial yang menjadi penunjang terbentuknya masyarakat madani itu sendiri. Unsurunsur sosial itulah yang kemudian menjadi pengikat yang menyatukan dan membangun masyarakat madani itu sendiri tanpa harus dipisahpisahkan, sehingga menjadi sebuah konsep ideal dalam hidup berbangsa dan bernegara.

Diantara unsur-unsur sosial pokok yang harus dimiliki oleh masyarakat madani menurut Arendt dan Habermas sebagaimana dikutif oleh M. Mawardi adalah (Mawardi, 2008: 21): wilayah publik yang bebas 
(free public sphere), demokrasi, toleransi, kemajemukan (pluralism) dan keadilan sosial (sosial justice).

The Free Public Sphere, ruang publik secara teoritik dapat diartikan sebagai wilayah dimana masyarakat sebagai warga negara memiliki akses penuh terhadap setiap kegiatan publik. Warga negara berhak melakukan kegiatan secara merdeka dalam mengemukan pendapat, berserikat, berkumpul, serta mempublikasikan penerbitan yang berkenaan dengan kepentingan umum. Institusionalisasi kepentingan umum ini menurut Hebermas antara lain berupa media massa, sekolah, gedung-gedung pertemuan umum dan parlemen (Asrori S. Kamil, 2008 30). Perjuangan penciptaan ruang publik yang bebas ini, bagi Arendt merupakan prasyarat untuk menciptakan sebuah masyarakat politik yang mampu melawan hegemoni negara. Sebab, hanya dalam ruang publik yang bebaslah, sebuah tindakan politik yang sebenar-benarnya mampu mengangkat harkat dan martabat kemanusiaan itu sendiri. Dan pada ruang publik yang bebaslah individu dalam posisinya yang setara mampu melakukan transaksitransaksi wacana dan praksis politik tanpa mengalami distorsi dan kekhawatiran. Sebagai sebuah prasyarat, maka untuk mengembangkan dan mewujudkan masyarakat madani dalam sebuah tatanan masyarakat, maka free publik sphere menjadi salah satu bagian yang harus diperhatikan. Karena dengan menafikan adanya ruang publik yang bebas dalam tatanan masyarakat madani, maka akan memungkinkan terjadinya pembungkaman kebebasan warga negara dalam menyalurkan aspirasinya yang berkenaan dengan kepentingan umum oleh penguasa yang tiranik dan otoriter.

Demokratis, merupakan suatu entitas yang menjadi penegak wacana masyarakat madani, dimana dalam menjalani kehidupan, warga negara memiliki kebebasan penuh untuk menjalankan aktivitas kesehariannya, termasuk berinteraksi dengan lingkungan sosialnya. Lebih jauh Azyumardi Azra menyampaikan bahwa demokrasi merupakan sebuah langkah yang mewadahi pemberdayaan (empowerment) masyarakat dalam berbagai aspek kehidupan, bukan hanya politik, tetapi juga sosial, budaya, pendidikan, ekonomi dan lainny (Azra, 1999: 6). Lebih lanjut ia mengungkapkan bahwa dalam hal ini demokratisasi lebih dipahami sebagai sebuah upaya perbaikan ketimbang memahami demokratisasi sebagai dalil pembenaran dalam melawan negara. Oleh karena itu, lagilagi demokrasi menempatai peran sentral dalam terbentuknya masyarakat madani. 
Toleran, merupakan sikap yang dikembangankan dalam masyarakat madani untuk menunjukan sikap saling menghargai dan menghoramti aktivitas yang dilakukan oleh orang lain. Atau dalam bahasa Mukti Ali, mengatakan sebagaimana dikutip oleh Thohir Luth agree in disagree (setuju dalam perbedaan) (Thohir Luth, 2006: 77), Artinya rasa toleran itu kalo dilahat dalam asfek agamis bukan berarti kita menjual prinsip kebenaran, apalagi menukarnya dengan harga yang murah. Demikian juga, rasa toleran ini tidak diartikan untuk meyakini kebenaran orang lain, padahal menurut kita hal itu adalah sesuatu yang tidak benar. Rasanya hal ini hanya mengakomodir persoalan-persoalan kemasyarakatan dalam tataran hubungan sosiologis. senada dengan itu Azra pun menyatakan bahwa dalam kerangka menciptakan kehidupan yang berkualitas dan berkeadaban (tamaddun/ civility), masyarkat madani menghajatkan sikap-sikap tolerannsi, yakni kesediaan individuindividu untuk menerima beragam perbedaan pandangan politik, budaya, agama dan lainya dikalangan bangsa (Tim ICCE UIN Syarif Hidayatullah Jakarta, 2008: 203). Dengan demikian, adanya sikap toleransi menjadi salah satu elemen penting pula yang menunjang tercipnya masyarakat madani, sebagaimana sikap toleran itu pula telah dipesankan dalam Al-Quran yang tertera dalam surat Al-Hujurat ayat 13 (lihat surat Al-Hujurat).

Pluralisme atau kemajemukan, merupakan pertalian sejati kebhinekaan dalam ikatan-ikatan keadaban. Bahkan pluralisme adalah suatu keharusan bagi keselamatan umat manusia antara lain melalui mekanisme pengawasan dan pengimbangan sebagaimana yang diungkapkan oleh Nurholis Madjid (Tim ICCE UIN Syarif Hidayatullah Jakarta, 2008: 204). Kemajemukan dalam pandangan Madjid pula, erat kaitannya dengan sikap penuh pengertian, kepada orang lain, yang nyata-nyata diperlukan dalam masyarakat yang majemuk. Secara islam juga kemajumakan sudah memang merupakan ketetapan Allah yang harus kita terima bersama sebagai sebuah romantika keindahan dalam hidup bermasyarakat.

Keadilan Sosial, satu lagi syarat utama terciptanya masyarakat madani yakni adanya keadilan sosial. Keadilan sosial yang dimaksudkan disini adalah keadilan yang harus dirasakan oleh masyarkat yang diberikan oleh negara baik dalam bidang ekonomi, politik dan hak-hak yang lainnya. Selain itu lebih sederhana lagi keadilan sosila yang dimaksud disini adalah adanya keseimbangan dan pembagian yang 
proporsional terhadap hak dan kewajiban setiap warga negara yang mencakup seluruh aspek kehidupan.

\section{Masyarakat Madani (Civil Society) di Lombok: Paradigma dan Praktik}

Indonesia memiliki tradisi kuat civil society (masyarakat madani). Bahkan jauh sebelum negara bangsa berdiri, masyarakat sipil telah berkembang pesat yang diwakili oleh kiprah beragam organisasi sosial keagamaan dan pergerakan nasional dalam perjuangan merebut kemerdekaan (Tim ICCE UIN Syarif Hidayatullah Jakarta, 2008: 204). Selaras dengan itu saya kira tidak berlebihan kiranya jika kita melihat keberadaan civil society dalam konteks Lombok. Artinya jika kita lihat fakta sejarah yang ada, di Lombok pun sejak jauh hari sebelum kemerdekaan dikumandangkan pada tanggal 17 Agustus 1945 telah ada tradisi civil society yang berkembang. Ini terbukti dengan terbentuknya organisasi-organisasi kemasyarakatan atau komponen-komponen civil society, seperti Nahdlatul Wathan (NW), Marakit'alim, Yatofa dan yang lainnya.

Khusus untuk NW misalnya. Jika kita membuka lembaran sejarahnya kembali, maka kita akan menemukan bahwa organisasi yang didirikan oleh TGKH. Muhammad Zainuddin Abdul Madjid ini, cikal bakalnya telah lahir sejak sebelum kemerdekaan Indonesia. Dimana pada waktu itu TGKH. Muhammad Zainuddin Abdul Madjid sepulangnya belajar dari Makkah ia mengadakan sebuah khalaqoh pengajian untuk masyarakat setempat. Setelah khalaqoh tersebut semakin semarak dan ramai, lalu kemudian ia melembagakannya menjadi sebuah pesantren kecil yang dinamakan pesantren Al-Mujahidin pada Tahun 1934 (Noer, dkk, 2004: 181). Pendirian pesantren al mujahidin inilah yang kemudian dalam perjalanannya menjadi cikal bakal berdirinya NW itu sendiri. Walaupun dalam perosesnya NW itu sendiri baru resmi didirikan pada tanggal 1 Maret 1953, (Noer, dkk, 2004: 205). Kendati demikian, tapi minimal cikal bakal lahirnya NW itu sendiri wadahnya sudah ada sejak Tahun 1934. Pendirian pesantren al-Mujahidin yang menjadi cikal bakal berdirinya NW inilah yang kemudian menurut hemat saya menjadi bukti bahwa wadah civil society telah ada sebelum kemerdekaan di Lombok.

Selain itu, terdapat hal penting yang harus kita perhatikan dalam melihat keberadaan komponen civil society yang ada di Lombok. NU dan Muhammadiyah sebagai organisasi terbesar di Indonesia juga tidak 
luput dalam peta civil society, karena bagaimanapun pula dua organisasi ini juga sebenarnya sudah menyebar ke Lombok sejak didirikannya. NU mislanya sejak berdirinya memiliki hubungan yang historis dengan NW, bahkan pendirinya pun yakni TGKH. Zainuddin Abdul Madjid pernah menjadi konsulat NU untuk Sunda Kecil sebelum resmi mendirikan NW itu sendiri (Noer, dkk, 2004:245). Selain itu juga NU sendiri untuk di Lombok memiliki banyak jamaah dan simpatisan terbukti dengan adanya pengurus wilayah dan cabang yang terdapat di masing-masing kabupaten kota di Lombok, belum lagi juga terdapat pondok -pondok pesantren yang secara jelas membawa payung NU seperti pondok pesantren Bagu di Peraya Lombok Tengah. Sedangkan untuk Muhammadiyah sendiri juga telah ada sejak lama di Lombok, hal ini terbukti dengan adanya pengurus wilayah dan cabang yang terbentuk di masing-masing kabupaten kota, belum lagi dengan keberadaan lembaga pendidikannya yang terdapat dimana-mana terutama di kota mataram. Oleh karena itu dua organisasi ini juga tentu menjadi bagian penting dari keberadaan civil society di Lombok.

Keberadaan Organisasi-organisasi tersebut-terutama NW yang lahir dan terbesar di Lombok-selain berperan sebagai organisasi perjuangan penegakan HAM, pendidikan, sosial dan perlawanan terhadap kekuasaan kolonial, telah menunjukkan pula kiprahnya sebagai komponen penting dalam civil society di Lombok. Kemandirian dan kesukarelaan para founding father, pengurusnya dan anggota organisasi tersebut merupakan karakter khas dari sejarah masyarakat madani di Lombok dan bahkan di Indonesia.

Namun, jika kita melihat Lombok hari ini maka kita akan melihat adanya perkembangan komponen-komponen civil society yang cukup dinamis. Artinya terdapat banyak lembaga-lembaga non-pemerintah seperti LSM, paguyuban, perkumpulan dan laninnya yang lahir di lombok, misalnya saja telah lahir LSM besar seperti Amphibi, Hizbullah, Satgas, Jejak Putih, Elang Merah dan lain sebagainya. Belum lagi organisasi-organisasi lainnya yang bergerak dalam wilayah yang berbeda. Data di atas membuktikan bahwa perkembangan civil society dalam asfek kuantitas terus bertambah banyak dari tahun ke tahun, namun kadang fakta di atas tidak berjalan sebanding dengan kualitas yang diharapkan ideal dalam wujud dan perannya sebagai civil society. Bagaimana tidak, karena sering kali wadah civil society itu sendiri kadang dalam prakteknya seringkali dijadikan modal sosial (social 
capital) oleh para elitnya untuk kepentingan pribadinya. Ini tentu menjadi hal yang sangat ironis jika melihat peran civil society yang sesungguhnya sangat mulia. Oleh karena itu, keberadaan komponen civil society di Lombok dalam asfek kuantitasnya terus bertambah dari tahun ke tahun, namun kualitasnya kadang masih dipertanyakan walaupun memang tidak semuanya seperti itu.

Berdasarkan deskripsi dan paradigma di atas, pengembangan masyarakat madani di Lombok selayaknya tidak hanya terpaku dalam model pengembangan dengan mengedepankan kuantitas, tapi sebaliknya, untuk mewujudkan masyarakat madani yang seimbang, ideal dan mandiri, maka dibutuhkan gabungan strategi dan paradigma berpikir. Sehingga masyarakat madani itu mampu menjadi wadah ideal untuk menciptakan stabilitas sosial.

Tidak seperti apa yang diungkapakan oleh M. Dawam Raharjo yang menyatakan bahwa masyarakat madani di Indonesia, masih merupakan lembaga-lembaga yang dihasilkan oleh sistem politik refresif. Ciri kritisnya lebih menonjol daripada ciri konsturktifnya. Mereka menurutnya, lebih banyak melakukan protes daripada mengajukan solusi, lebih banyak menuntut daripada memberi sumbangan terhadap pemecahan masalah (Raharjo, 2000:18-22). Hal ini sering kali dipicu karena pola pikir elit masyarakat madani yang apourtunis dan pragmatis.

Senada dengan Raharjo, menurut AS. Hikam juga menyatakan, karakter masyarakat madani di Indonesia masih sangat bergantung terhadap negara sehingga selalu berada pada posisi subordinat, khususnya bagai mereka yang berada pada strata sosial bawah (Tim ICCE UIN Syarif Hidayatullah Jakarta, 2008: 206). Karena itu seringkali wadah masyarakat madani hanya jadi boneka penguasa semata. Oleh sebab itu, pendapat-pendapat di atas masih sangat relevan dengan melihat realitas praktek wadah sebagian masyarakat madani baik di Lombok maupun di Indonesia dalam skala yang lebih luas.

\section{Urgensitas Masyarakat Madani (Civil Society) Sebagai Alternatif Solusi Konflik di Lombok}

Berbicara masyrakat madani di Lombok kiranya menjadi sangat penting jika melihat peran masyarakat madani itu sendiri dalam mengurai sebuah konflik, atau setidaknya masyarakat madani itu sendiri dapat menjadi langkah preventif dalam menghadapai kemungkinan- 
kemungkinan terjadinya konflik. Apalagi jika kita melihat karateristik masyarkat madani yang di dalamnya terdapat nilai-nilai luhur keadilan sosial, pluralisme, toleransi, demokrasi dan ruang publik yang bebas. Berangkat dari itu, sangat beralasan kemudian jika konsep masyarakat madani itu dapat menjadi penting dalam kehidupan masyrakat. Apalagi hal semacam itu dapat dikembangkan dan dilakukan di daerah-daerah yang biasanya sering terjadi konflik, misalnya saja di Lombok, Bima atau daerah lainnya di Indonesia. Dengan demikian tidak berlebihan kiranya jika gagasan mengenai konsep masyarkat madani dapat dijadikan alternatif solusi dalam mengurai konflik-konflik yang ada.

Lombok misalnya yang menjadi fokus bahasan dalam artikel ini, setidaknya dalam satu dasawarsa terakhir ini, kerap kali terusik oleh serangkaian konflik yang terjadi di mana-mana (Suprapto, 2011:22). Tentu hal ini sangat kontras dengan kesan Lombok yang selama ini tersematkan dengan tanah yang aman, toleran, damai dan indah. Namun setidaknya jika kita mengidentifikasi model konfliknya sendiri, maka untuk kasus Lombok masalah perbedaan agama, sering kali menjadi penyebab konflik dalam masyarakat, di sisi lain perbedaan agama tidak jarang dijadikan sebagai alat pemicu munculnya konflik dalam masyarakat oleh pihak-pihak tertentu yang berkepentingan untuk mencapai tujuan tertentu di luar tujuan yang berkaiatan dengan kepentingan keagamaan. Tidak hanya itu, dalam masyarakat terkadang terjadi konflik internal agama yang diakibatkan oleh adanya perbedaan pemahaman nilai-nilai agama atau keyakinan. Disamping itu untuk kasus di Lombok juga sering kali terjadi konflik akibat adanya kesalah pamahaman antar warga sehingga konfliknya juga bertipologi konflik lokal antar kampung seperti yang sering terjadi di Ketara, Lombok Tengah.

Lebih jauh, konflik sosial akibat SARA telah menimbulkan kerugian besar bagi masyarakat maupun pemerintah, dari sisi materiil yakni hancurnya infrastruktur yang ada dan hilang/ rusaknya harta kekayaan. Lebih dari itu konflik juga berdampak pada sosio-psikologik dan sosiokultural yang memprihatinkan bagi masyarakat dimana konflik terjadi. Konflik sosial tersebut telah menimbulkan depresi sosial, traumatik, keinginan balas dendam, dan menguatnya fenomena social tention, cultural disintegration dan rendahnya sosial trust terhadap pemerintah maupun terhadap kelompok masyarakat (Marzali dkk, 2003). Konflik sosial yang melanda masyarakat Lombok dan dunia kita ini biasanya 
berakar dan berimplikasi pada konflik nilai secara holistik (pandangan hidup, kebenaran, moral, transendental). Tiap pribadi memiliki konflik dalam dirinya dan dengan orang lain karena perbedaan pendapat dan pandangan hidup. Konflik sosial kadang muncul sering kali karena keterlambatan penanganan kasus individual berdasarkan penerapan hukum yang adil oleh aparat keamanan.

Untuk memperkuat bahasan di atas, setidaknya juga terdapat beberapa teori yang mencoba menjelaskan tentang sebab terjadinya konflik. Salah satu diantaranya yang dikemukakan oleh Simon Fisher dkk, yang dikutif oleh Suprapto menyebutkan ada beberapa sebab terjadinya konflik (Suprapto, 2011, 23-24). Pertama, teori hubungan masyarkat, yang menyatakan bahwa konflik terjadi disebabkan oleh polarisasi yang terus terjadi, ketidak percayaan dan permusuhan di antara kelompok yang berbeda dalam masyarakat. Kedua, teori negosiasi konflik, yang menganggap bahwa konflik terjadi oleh posisiposisi yang tidak selaras dan perbedaan pandangan tentang konflik oleh pihak-pihak yang mengalami konflik. Ketiga, teori ketuhanan manusia, yang menganggap bahwa konflik disebabkan oleh kebutuhan dasar manusia yang tidak terpenuhi atau terhalangi. Keempat, teori identitas yang berasumsi bahwa konflik disebabkan oleh karena identitas yang sering berakar pada hilangnya sesuatu atau penderitaan dimasa lalu yang tidak diselesaikan. Kelima, teori kesalahpahaman antarbudaya, yang berasusmsi bahwa konflik seringkali juga disebabkan karena adanya kesalahan dalam penafsiran dalam mengaktualisasikan atau mengkomunikasikan budaya di daerah yang berbeda. Keenam, teori transformsi konflik, yang menyatakan konflik disebabkan oleh ketidaksetaraan dan ketidak adilan yang muncul sebagai masalahmasalah sosial, budaya dan ekonomi.

Dengan demikian, secara umum ada beberapa penyebab terjadinya konflik sosial. Pertama, pada tataran makroskopik, konflik sosial disebabkan oleh adanya kebijakan pemerintah dalam segala bidang yang sentralistik dengan dampak ketimpangan dan ketidak adilan dalam bidang ekonomi, hukum, politik dan budaya. Kedua, pada tataran mikroskopik, konflik sosial bernuansa agama sebagai akibat dari adanya kebijakan yang kurang memperhatikan kehidupan sosial keagamaan masyarakat lokal (Natsir, 2009: 3).

Berdasarkan teori-teori konflik di atas, sangat relvan rasanya jika melihat model varian konflik yang terjadi di Lombok, misalnya: (a) 
konflik keagamaan yang meliputi, kasus ahmadiyah dengan masyarakat, konflik aliran salafi dengan masyarakat, konflik warga desa gerung praya dengan tarekat siratul mustakim, konflik NW Pancor dengan NW Anjani, kasus 171 perusakan gereja oleh masyarkat, dan kasus-kasus ketegangan hindu muslim. (b) konflik antar kampung yang meliputi: konflik antar kampung Ketare dan Batujai, Ketare dengan Penujak, Ketare dengan Sengkol, Karang Genteng dan Petemon. Dan (c) konflik yang disebabkan oleh faktor ekonomi politik yang meliputi: konflik pembangunan Bandara Intrnasional Lombok, PNS dengan pemda Lombok Timur (Suprapto, 2011, 29-31). Ironisnya lagi konflik-konflik ini hampir merata terjadi di seluruh kabupaten kota di Lombok seperti Kota Madya Mataram, Lombok Timur, Lombok Tengah, Lombok Barat dan Lombok Utara.

Dengan melihat data dan realitas konflik di atas, tentu kita tidak bisa tinggal diam. Dengan demikian untuk menyikapi hal ini diperlukan sejumlah upaya untuk mengatasinya. Menurut hemat saya, disilah kemudian pentingnya masyarakat madani (civil society) dijadikan sebagai alternatif sebagai solusi dari berbagai permasalahan tersebut. Apabila agenda mulia dari konsep masyarakatr madani tersebut, jika berkerja dengan baik maka tentu masalah-masalah tersebut akan dapat terselesaikan dengan baik pula, tanpa harus adanya korban jiwa dan lain sebagainya.

Gagasan ini tentu sejalan dengan para cendikiawan muslim indonesia yang intens dalam mengamati gejala-gejala di atas, seperti Nurkholis Madjid, M. Dawam Raharjo, Azyumardi Azra dan yang lainnya, yang berpandangan sama dengan menyuarakan pentingnya penyelesaian konflik dengan pendekatan persuasif, yang mengedepankan asfek toleransi, pluralisme, demorasi, dan dialog terbuka. Tentu hal ini mereka maksudkan dengan penyelesaian menggunakan model konsep-konsep masyarakat madani. Oleh sebab itu, untuk kasus konflik di Lombok kiranya akan sangat relevan jika menggunakan konsep tersebut, dengan model kerja yang tentunya memaksimalkan peran komponen-komponen masyarkat madani yang ada, seperti lembaga NW, NU, Muhammadiyah dan wadah-wadah masyarkat madani yang lainnya.

Ide-ide ini tampaknya cukup mudah dapat dilakukan, asalkan ada komitmen dan keinginan kuat dari seluruh komponen masyarakat madani itu sendiri untuk melakukan hal tersebut, dengan cara 
memperbanyak membuka diaolog dan pendekatan persuasif atau advokasi terhadap masyarakat atau elit yang berkonflik. Sehingga, dengan upaya itu masyarakat akan semakin sadar dan tumbuh rasa toleransinya di tengah perbedaan yang ada. Peran komponen masyarakat madani ini tentu menjadi sangat strategis jika melihat posisinya yang berada di luar pemerintah, yang notabene tidak terkooptasi oleh kepentingan pemerintah atau negara dalam posisinya yang ideal. Oleh sebab itu, sudah saatnya komponen-komponen masyarkat madani itu untuk bekerja dalam formatnya yang ideal demi terciptanya tatanan masyarkat yang adil, aman, harmonis dan tentunya juga dengan upaya itu diharapkan dapat menekan atau mencegah terjadinya konflik-konflik yang lain.

\section{KESIMPULAN}

Penguatan peran komponen-komponen masyarakat madani (civil society) dalam mengurai atau mengatasi konflik di Lombok menjadi hal yang sangat urgen. Pengembangan dan penerapan nilai-nilai masyarakat madani tetu harus menjadi perioritas utama dalam masyarakat sehingga dapat terciptakan suasana damai, aman, dan harmonis. Cita-cita ini tentu tidak akan pernah dirasakan tanpa ada komitmen dan kemauan yang kuat dari seluruh komponen masyarkat madani untuk mencoba menerapkan gagasan tersebut. Oleh sebab itu, kita berharap ide-ide tersebut bisa dijadikan sebagai salah satu model dalam mencegah dan mengurai konflik-konflik yang ada, terutama di Lombok.

Tentu saja penerapan dan pilihan model alternatif mengurai konflik di atas hendaknya diikuti oleh serangkaian upaya pemerintah juga yang menjadi elemen penting dalam menciptakan suasana aman tersebut. Dalam hal ini pemerintah diharapkan terus berperan aktif menjadikan komponen masyarakat madani tersebut sebagai mitra dalam menangani kasus-kasus konflik, bukan malah sebaliknya. Dengan upaya terpadu seperti itu, maka pasti konflik-konflik yang ada akan dapat diselesaikan dengan damai tanpa ada konflik dan korban jiwa lagi. 


\section{DAFTAR PUSTAKA}

Asnawi. 2006. Agama dan Paradigma Sosial Masyarakat: Menykapi Pemahaman Masyarakat Sasak Tentang Taqdir Allah dan Kematian Bayi. Jakarta: Centra Media.

Azra, A. 1999. Menuju Masyarakat Madani, Gagasan, Fakta dan Tantangan. Bandung: PT. Remaja Rosda Karya.

Al-Munawar, S. A. H. dkk. 2003. Agenda Generasi Intelektual Ikhtiar Membangun Masyarakat Madani.Jakarta: Penamadani, 2003.

Dhofier, Z. 2011. Tradisi Pesantren: Studi Tentang Pandangan Hidup Kyai. Jakarta: LP3ES. Cet. 8.

Fikri, H. K. (2018). Agama dalam Eksistensi Pemahaman Tradisionalis Masyarakat Indonesia: Upaya Membedah Agama Perspektif Tradisional Ektrem dan Antisipasi Konflik Bermotif Agama. SANGKéP: Jurnal Kajian Sosial Keagamaan, 1(1), 49-60.

Hidayat, K. dan Gaus, A.F. (ed). 2005. Islam, Negara dan Civil Society, Gerakan dan Pemikiran Islam Kontemporer. Jakarta: Paramadina.

Ibrahim, A. 1996. Islam dan Masyarakat Madani dalam Aswab Mahasin (ed.) Ruh Islam dan Budaya Bangsa. Jakarta: Yayasan Festival Istiqlal.

Jainuri, A. 2000. Agama dan Masyarakat Madani, Jurnal Al-Afkar, Edisi III, Tahun ke 2 : Juli-Desember.

Kukathas, C. 2004. Islam, Masyarakat Sipil, dan Ekonomi Pasar, dalam Atilla Yahya (ed),.Jakarta: Fredrick Nauman Stiftung, 2004.

Luth, T. 2006. Masyarakat Madani Solusi Damai Dalam Perbedaan. Jakarta: MEDIACITA, 2006.

Gorski, E. 2007. Civil Society, Pluralism and Universalism. Washington, D.C., United State of America, 2007.

Mawardi, M. 2008. Strategi Pemberdayaan Masyarakat Madani, Jurnal Pengembangan Masyarakat Islam, Volume 4, Nomor 1, Juni.

Majid, N. 1999. dalam Islam, Masyarakat Madani dan Demokrasi, Sudarno Shobron (ed). Surakarta: Muhammadiyah Universitu Press, 1999.

Marzali, A. dkk. 2003. Konflik Komunal di Indonesia Saat Ini. Jakarta: INIS, 2003.

Natsir, M. dkk. 2009. Pemetaan Kerukunan Hidup Beragama di Lombok, Laporan Penelitian.

Noer, M. Dkk. 2004. Visi Kebangsaan Religius: Refleksi Pemikiran dan Perjuangan TGKH Muhammad Zaenuddin Abdul Madjid 1904-1997. Jakarta: Logos Wacana Ilmu, 2004. cet. 1. 
Karni, A. S. 1999. Civil Society dan Ummah; Sintesa Diskursif Rumah Demokrasi. Jakarta: Logos, 1999.

Sufyanto. 2001. Masyarakat Tamaddun, Kritik Hermeneutis Masyarakat Madani Nurcholish Madjid. Yoyakarta: Pustaka Pelajar, 2001.

Syamsuddin, D. 1999. Etika Agama dalam membangun Masyarakat Madani. Jakarta : Gramedia Pustaka Utama, 1999.

Suprapto. 2011. Penguatan Kearifan Lokal Untuk Resolusi Konflik dan Upaya Bina Damai di Pulau Seribu Masjid, dalam Jurnal IndoIslamika, Volume 1, Nomor 1.

Tim ICCE UIN Jakarta. 2008. Pendidikan Kewarganegaraan, Demokrasi, HAM dan Masyarakat Madani. Jakarta: ICCE UIN Syarif Hidayatullah Jakarta. 1999. Masyarakat Madani: Agama, Kelas Menengah dan Perubahan Sosial. Jakarta: Pustaka LP3ES, 1999.

Rahardjo, M. D. 2000. Sejarah Agama dan Masyarakat Madani, dalam Membongkar Mitos Masyarakat Madani. Yogyakarta: Pustaka Pelajar.

Yusron. 2009. Elit Lokal dan Civil Society.Jakarta: LP3ES. 